\title{
PROPORTION OF ROOT PRODUCTION IN SEVERAL TEMPERATE GRASSLANDS OF CENTRAL EUROPE
}

\author{
KAREL FIALA $^{1^{*}}$, IVAN TŮMA ${ }^{2}$, PETR HOLUB $^{3}$ \\ ${ }^{1}$ Department of Vegetation Ecology, Institute of Botany, Academy of Sciences of the Czech Republic, Lidická 25, 602 \\ 00 Brno, Czech Republic; e-mail: karel.fiala@ibot.cas.cz \\ ${ }^{2}$ Department of Agrochemistry, Soil Science, Microbiology and Plant Nutrition, Faculty of Agronomy, Mendel Uni- \\ versity in Brno, Zemědělská 1, 61300 Brno, Czech Republic; e-mail: tuma@node.mendelu.cz \\ ${ }^{3}$ Global Change Research Centre, Academy of Sciences of the Czech Republic, Bělidla 4a, 60300 Brno, Czech Re- \\ public; e-mail: holub.p@czechglobe.cz
}

* Author for correspondence

\begin{abstract}
Fiala K., Tůma I., Holub P.: Proportion of root production in several temperate grasslands of Central Europe. Ekológia (Bratislava), Vol. 33, No. 3, p. 232-241, 2014.

Variability in $f_{\mathrm{RNPP}}$, defined as the fraction of root net primary productivity (RNPP) to total net primary productivity (TNPP) [above-ground net primary productivity (ANPP) + RNPP] were examined through synthesis of 40 samples from available field biomass data assessed by in-growth core and obtained at 13 grassland sites situated in different altitudes in the Czech and Slovak Republics. Results indicate that $f_{\text {RNPP }}$ varied from 0.05 to 0.59 across the compared sites. Submontane wet meadows had larger $f_{\text {RNPP }}$ and dry lowland grasslands had smaller $f_{\text {RNPP. }}$ However, extreme conditions of mountain sites were reflected in a decrease of $f_{\mathrm{RNPP}}$. Thus the relationship between values of $f_{\text {RNPP }}$ at different sites and altitudes was indicated by quadratic regression with the highest $f_{\text {RNPP }}$ coefficients in middle altitudes, where there were sufficient amounts of precipitation together with not so extremely cold temperatures. Results also indicate a high variability in $f_{\text {RNPP }}$ at a regional scale and along increasing altitude. These data show how important and different roles grasslands can play in accumulation and turnover of root biomass.
\end{abstract}

Key words: altitude, biomass partitioning, grassland, net primary productivity, precipitation, temperature.

\section{Introduction}

Root systems are a fundamental part of grassland vegetation, because root mass and rhizosphere represent here the main pool of organic matter and geobioelements (e.g. Rychnovská, 1983; Stanton, 1988; Hui, Jackson, 2006). It is important to understand how habitat variability affects soil carbon (C) pools/fluxes, particularly, as these ecosystems store up to $30 \%$ of the world below-ground C (see Risch et al., 2007). Therefore, grasslands play a significant role in the global C cycle.

Net primary productivity and biomass partitioning are strongly influenced by climate (e.g. Melillo et al., 1993; Gill, Jackson, 2000; Ni, 2004). For example, above-ground net 
primary productivity (ANPP) is positively correlated and showed a significant linear relationship with mean annual precipitation (MAP) in grasslands (e.g. Köchy, Wilson, 2004; Yahdjian, Sala, 2006; Fay et al., 2008). However, contradictory data on root growth and below-ground biomass in dry conditions were published. Root biomass and total fine root length were significantly higher at the dry site than at the humid site (e.g. Ibrahim et al., 1997; Bakker et al., 2006; Qaderi et al., 2006). On the other hand, results of other authors indicate that root biomass and root length were lower in the drought year than in the wet year (e.g. Hayes, Seastedt, 1987; Andrzejewska, 1991; Titlyanova et al., 1999). Also Hui and Jackson (2006) found strong negative relationships of root fraction with mean annual temperature (MAT) and MAP across sites, however, temporal relationships of root fraction and climatic variables within sites were more complicated and site-specific. They synthesised 94 site-year field biomass data at 12 grassland types around the world from net primary productivity database and from the literature. This analysis provides the first synthesis of geographical variability and its relationships with climatic variables for grassland roots. Their results showed that the fraction $\left(f_{\mathrm{BNPp}}\right)$ of below-ground net primary productivity (BNPP) to TNPP varied from 0.40 to 0.86 across analyzed sites (mainly from USA, China and Russia). But there were only a few data from Europe and no data were included from central part of Europe. Hui and Jackson (2006) deduced from their comparison that $f_{\text {BNPP }}$ was negatively correlated with MAT and MAP. However, results of some authors (see text above) indicated an opposite relationship. Nevertheless, Hui and Jackson (2006) noticed that it is still unclear how large the impact of climate change will be on terrestrial C sequestration and cycling, and that additional data on geographical and interannual variability in below-ground biomass components are greatly needed. Thus a gap in knowledge still exists in comparison of root growth in various grasslands situated at different condition of various regions. This fact inspired us to study the role of the various temperate grasslands, their root production, in the regional $\mathrm{C}$ cycles.

Therefore, the aim of our study was to compare impacts of various grassland communities occurring in different regions on their root production, which was assessed by in-growth soil core technique. Applied the same methodological approach enables us to compile available data on field biomass measurements occurring in temperate grasslands of the Czech and Slovak Republics (Central Europe). Forty site-year field root biomass data at 13 grassland types were gathered from published original papers (see Material and methods). Thus a large collection of root samples, performed in the same way, enable us to determine the patterns and potential mechanisms of variation in $f_{\text {RNPp }}$ for these grassland ecosystems. We were particularly interested in altitudinal variability in $f_{\mathrm{RNPP}}$ and relationships with MAT and MAP.

We hypothesised that: (1) As dry and warm conditions can cause reductions in root growth, we expected to find the lower root increments and lower biomass allocation into root biomass in drier condition at warmer sites in contrary to wet and cool highlands and mountains. (2) We expected that root production will be a simple linear function of altitude, precipitation and temperature. (3) We presume that analyzed study sites can be clustered, at least, into three main groups based on variability in $f_{\mathrm{RNPP}}$ associated with regions and given by climatic parameters. 


\section{Material and methods}

\section{Study site}

The 40 site-year samples of roots, collected along altitudinal gradient and reflected large differences in MAT and MAP, encompassed several major grassland types or regions, including temperate dry grasslands, alluvial meadows, submontane wet meadows, mountain clear-cut grasslands and expanding grass stands dominated by Calamagrostis epigejos (Tables 1 and 2). The data set used in this study was obtained from mostly available recent publications (see Table 2) and data originate from natural growing field conditions. All sites were dominated by C3 species. Sites were not fertilised, only some of them were extensively mowed.

T a b l e 1. Location and characteristics of the nine grassland sites in Czech (CR) and Slovak (SR) Republics.

\begin{tabular}{|c|c|c|c|c|c|c|}
\hline Site (region) & $\begin{array}{c}\text { Latitude } \\
\text { longitude }\end{array}$ & $\begin{array}{l}\text { Altitude } \\
\text { (m a.s.l.) }\end{array}$ & $\begin{array}{c}\text { Grassland } \\
\text { types }\end{array}$ & $\begin{array}{c}\text { MAT } \\
\left({ }^{\circ} \mathrm{C}\right)\end{array}$ & $\begin{array}{l}\text { MAP } \\
(\mathrm{mm})\end{array}$ & Soil type (bedrock) \\
\hline $\begin{array}{l}\text { Lednice, CR (Flood } \\
\text { plain South Moravia) }\end{array}$ & $48^{\circ} 49^{\prime} 16^{\circ} 48^{\prime}$ & 160 & $\begin{array}{l}\text { Alluvial } \\
\text { meadow }\end{array}$ & 9.0 & 524 & $\begin{array}{l}\text { Gleyed soil (alluvial } \\
\text { sediments) }\end{array}$ \\
\hline $\begin{array}{l}\text { Nejdek, CR (Flood } \\
\text { plain South Moravia) }\end{array}$ & $48^{\circ} 48^{\prime} 16^{\circ} 47^{\prime}$ & 160 & $\begin{array}{l}\text { Alluvial } \\
\text { meadow }\end{array}$ & 9.0 & 524 & $\begin{array}{l}\text { Gleyed soil (alluvial } \\
\text { sediments) }\end{array}$ \\
\hline $\begin{array}{l}\text { Havraníky-Podyjí } \\
\text { National Park, CR } \\
\text { (Etchplain S. Moravia) }\end{array}$ & $48^{\circ} 48^{\prime} 15^{\circ} 59^{\prime}$ & 320 & $\begin{array}{c}\text { Dry } \\
\text { acidophilous } \\
\text { grassland }\end{array}$ & 8.5 & 471 & Ranker (granit) \\
\hline $\begin{array}{l}\text { Suchý vrch, SR } \\
\text { (Kremnické hills) }\end{array}$ & $48^{\circ} 44^{\prime} 19^{\circ} 09^{\prime}$ & 460 & $\begin{array}{l}\text { Montane } \\
\text { Trisetum } \\
\text { meadow }\end{array}$ & 7.7 & 853 & $\begin{array}{l}\text { Dystric Cambisol } \\
\text { (disintegrated } \\
\text { andesite) }\end{array}$ \\
\hline $\begin{array}{l}\text { Kameničky, CR } \\
\text { (Bohemian-Moravian } \\
\text { Highland) }\end{array}$ & $49^{\circ} 43^{\prime} 15^{\circ} 58^{\prime}$ & 624 & $\begin{array}{l}\text { Submontane } \\
\text { wet meadow }\end{array}$ & 6.8 & 786 & $\begin{array}{c}\text { Brown acid gleyed } \\
\text { soil (crystalline } \\
\text { rocks) }\end{array}$ \\
\hline $\begin{array}{l}\text { Černá Ostravice } \\
\text { valley, CR (Beskydy } \\
\text { Mts.) }\end{array}$ & $49^{\circ} 28^{\prime} 18^{\circ} 30^{\prime}$ & 630 & $\begin{array}{l}\text { Montane clear- } \\
\text { cut grassland }\end{array}$ & 7.1 & 869 & $\begin{array}{l}\text { Dystric planosol } \\
\text { (sandstone) }\end{array}$ \\
\hline $\begin{array}{l}\text { Bílý Kř́í̌, CR } \\
\text { (Beskydy Mts.) }\end{array}$ & $49^{\circ} 30^{\prime} 18^{\circ} 32^{\prime}$ & 945 & $\begin{array}{l}\text { Montane clear- } \\
\text { cut grassland }\end{array}$ & 6.5 & 948 & $\begin{array}{l}\text { Spodo-dystric } \\
\text { cambisol } \\
\text { (sandstone) }\end{array}$ \\
\hline $\begin{array}{l}\text { Kněhyně hill, CR } \\
\text { (Beskydy Mts.) }\end{array}$ & $49^{\circ} 30^{\prime} 18^{\circ} 18^{\prime}$ & 1240 & $\begin{array}{l}\text { Montane clear- } \\
\text { cut grassland }\end{array}$ & 3.7 & 1102 & $\begin{array}{l}\text { Spodo-dystric } \\
\text { cambisol } \\
\text { (sandstone) }\end{array}$ \\
\hline $\begin{array}{l}\text { Smrk hill, CR } \\
\text { (Beskydy Mts.) }\end{array}$ & $49^{\circ} 30^{\prime} 18^{\circ} 22^{\prime}$ & 1250 & $\begin{array}{l}\text { Montane clear- } \\
\text { cut grassland }\end{array}$ & 3.6 & 1146 & $\begin{array}{l}\text { Ferro-humic podzol } \\
\text { (sandstone) }\end{array}$ \\
\hline
\end{tabular}

Notes: MAT - mean annual temperature; MAP - mean annual precipitation.

\section{Data analysis}

In order to assess yearly root increments (root production), the in-growth core technique (Milchunas, 2012) was used in all sites (see Fiala, 1998, 2000, 2001; Fiala et al., 2009, 2012; Holub et al., 2013a, b; Tomaškin, Tomaškinová, 2012). The same method used in all sites enables us to compare reliably summarised data. For comparison of the amount of produced roots in various grasslands, $f_{\mathrm{RNPP}}$ coefficient was used (see Hui, Jackson, 2006). The $f_{\mathrm{RNPP}}$ was calculated using the equation:

$$
f_{\mathrm{RNPP}}=\mathrm{RNPP} /(\mathrm{ANPP}+\mathrm{RNPP}) \text {, }
$$


where RNPP is root net primary productivity and ANPP is above-ground net primary productivity. For calculations of $f_{\text {RNPP }}$ we used ANPP data, where sum of peak live biomass and fresh litter were estimated and available (Jakrlová, 1996; Holub, 2002; Hrabě et al., 2002; Fiala et al., 2004; Holub et al., 2012; Tomaškin, Tomaškinová, 2012). Method was applicable at all of the sampling sites. Root in-growth estimates performed in dense meadow stands represented more suitable method, mainly for comparison of root growth in various conditions. To study the relationships of $f_{\text {RNPP }}$ with climatic variables, MAT and MAP were collected for these sites (Table 1).

Statistical analysis

The regression analysis was conducted on relationships of root increments with altitude, MAT and MAP to determine whether these parameters are related. All statistical analyses were performed using statistical package STATISTICA 9 (Statsoft Inc., Tulsa, OK, US).

$\mathrm{T} \mathrm{a} \mathrm{b} \mathrm{le} \mathrm{2.} \mathrm{TBDM} \mathrm{(in} \mathrm{g} \mathrm{DM} \mathrm{m}^{-2} \mathrm{yr}^{-1}$ ), root increments (RNPP in $\mathrm{g} \mathrm{DM} \mathrm{m}^{-2} \mathrm{yr}^{-1}$ ) and relationships of the fraction of RNPP to TNPP $\left(\mathrm{f}_{\mathrm{RNPP}}\right)$ recorded on different sites (see also Table 1 ).

\begin{tabular}{|c|c|c|c|c|c|c|}
\hline Site & Region & Dominant species & Year & TBDM & RNPP & $\mathbf{f}_{\mathrm{RNPP}}$ \\
\hline \multirow{2}{*}{ Lednice $^{1}$} & Flood plain & \multirow{2}{*}{$\begin{array}{l}\text { Cirsium canum, } \\
\text { Deschampsia cespitosa }\end{array}$} & \multirow{2}{*}{$\begin{array}{c}1998- \\
1999\end{array}$} & 1562 & 98 & 0.20 \\
\hline & South Moravia & & & 1601 & 66 & 0.12 \\
\hline \multirow{2}{*}{ Lednice $^{1}$} & Flood plain & \multirow{2}{*}{ Calamagrostis epigejos } & \multirow{2}{*}{$\begin{array}{c}1998- \\
1999\end{array}$} & 1306 & 71 & 0.11 \\
\hline & South Moravia & & & 1552 & 61 & 0.07 \\
\hline \multirow{2}{*}{ Nejdek $^{1}$} & Flood plain & \multirow{2}{*}{$\begin{array}{l}\text { Serratula tinctoria, Poa } \\
\text { pratensis }\end{array}$} & \multirow{2}{*}{$\begin{array}{c}1998- \\
1999\end{array}$} & 1322 & 41 & 0.13 \\
\hline & South Moravia & & & 1462 & 92 & 0.14 \\
\hline \multirow{2}{*}{ Nejdek $^{1}$} & Flood plain & \multirow{2}{*}{ Calamagrostis epigejos } & \multirow{2}{*}{$\begin{array}{c}1998- \\
1999\end{array}$} & 1576 & 56 & 0.06 \\
\hline & South Moravia & & & 1576 & 61 & 0.07 \\
\hline \multirow{2}{*}{$\begin{array}{l}\text { Havraníky-Podyjí } \\
\text { National Park }\end{array}$} & Etchplain & \multirow{2}{*}{$\begin{array}{l}\text { Festuca ovina, Avenella } \\
\text { flexuosa, Pimpinella } \\
\text { saxifraga }\end{array}$} & \multirow{2}{*}{$\begin{array}{c}2001- \\
2005\end{array}$} & \multirow[b]{2}{*}{$1051 \pm 86$} & \multirow[b]{2}{*}{$100 \pm 26$} & \multirow[b]{2}{*}{$0.21 \pm 0.05$} \\
\hline & South Moravia & & & & & \\
\hline Suchý vrch ${ }^{3}$ & Kremnické hills & $\begin{array}{l}\text { Trisetum flavescens, Poa } \\
\text { pratensis }\end{array}$ & $\begin{array}{c}1991- \\
1998\end{array}$ & $831 \pm 93$ & $244 \pm 73$ & $0.37 \pm 0.15$ \\
\hline Kameničky ${ }^{4}$ & $\begin{array}{l}\text { Bohemian- } \\
\text { Moravian highland }\end{array}$ & $\begin{array}{l}\text { Cirsium palustre, } \\
\text { Deschampsia cespitosa }\end{array}$ & 1992 & 1917 & 157 & 0.24 \\
\hline Kameničky ${ }^{5}$ & \begin{tabular}{|l|} 
Bohemian- \\
Moravian highland \\
\end{tabular} & $\begin{array}{l}\text { Cirsium palustre, } \\
\text { Deschampsia cespitosa }\end{array}$ & $\begin{array}{c}2001- \\
2005 \\
\end{array}$ & $1821 \pm 146$ & $163 \pm 24$ & $0.25 \pm 0.04$ \\
\hline \multirow{2}{*}{$\begin{array}{ll}\text { Černá } & \text { Ostravice } \\
\text { valley }^{6} & \end{array}$} & \multirow{2}{*}{ Beskydy Mts. } & \multirow{2}{*}{ Calamagrostis villosa } & \multirow{2}{*}{$\begin{array}{c}1994- \\
1995\end{array}$} & \multirow{2}{*}{1998} & 359 & 0.51 \\
\hline & & & & & 319 & 0.33 \\
\hline \multirow{2}{*}{ Bílý Kř́íž } & \multirow{2}{*}{ Beskydy Mts. } & \multirow{2}{*}{ Calamagrostis villosa } & \multirow{2}{*}{$\begin{array}{c}1994- \\
1995\end{array}$} & \multirow{2}{*}{2234} & 136 & 0.27 \\
\hline & & & & & 135 & 0.24 \\
\hline Bílý Kř́íž & Beskydy Mts. & $\begin{array}{l}\text { Nardus stricta, Avenella } \\
\text { flexuosa }\end{array}$ & $\begin{array}{c}2001- \\
2005\end{array}$ & $1620 \pm 181$ & $162 \pm 46$ & $0.27 \pm 0.06$ \\
\hline \multirow{2}{*}{ Kněhyně hill ${ }^{6}$} & \multirow{2}{*}{ Beskydy Mts. } & \multirow{2}{*}{ Calamagrosatis villosa } & \multirow{2}{*}{$\begin{array}{c}1994- \\
1995\end{array}$} & \multirow{2}{*}{2592} & 80 & 0.14 \\
\hline & & & & & 35 & 0.05 \\
\hline \multirow{2}{*}{ Smrk hill ${ }^{6}$} & & & 1994- & & 20 & 0.06 \\
\hline & Beskydy Mts. & Calamagrostis villosa & 1995 & 875 & 22 & 0.06 \\
\hline
\end{tabular}

Year, measurements included in the analysis were made during these years. SE values are shown where available. Dominant species occurring in grasslands are also given.

RNPP data were obtained by Fiala 2001( $\left(^{1}\right)$; Fiala et al., 2012( ${ }^{(2)}$; Tomaškin, Tomaškinová, $2012\left({ }^{3}\right)$; Fiala et al., $2013\left({ }^{4}\right)$; Fiala et al., 2009(5,7); Fiala, 1998, $2000\left(^{6}\right)$. ANPP data published by Holub, $2002\left({ }^{1}\right)$; Fiala et al., $2004\left(^{2}\right)$; Holub et al., 2012(2,7); Tomaškin, Tomaškinová, 2012( $\left(^{3}\right)$; Hrabě et al., 2002( $\left(^{4}\right)$; Holub unpubl.( ${ }^{(5)}$; Jakrlová, 1996( $\left(^{(}\right)$were used (see Material and Methods). 


\section{Results}

\section{Variations in below-ground plant parts on different sites}

Summarised data on field biomass measurements, obtained in unfertilised temperate grasslands in the Czech and Slovak Republics (Central Europe), showed that root biomass data are rather variable (Table 2). Total below-ground dry mass (TBDM) varied in large range of values (from 831 to $2592 \mathrm{~g} \mathrm{DM} \mathrm{m}^{-2}$ ). Highland and mountain sites had higher amount of TBDM surpassed $2 \mathrm{~kg}$ of dry matter per $\mathrm{m}^{2}$.

Yearly root increments, estimated by in-growth core technique, were used to calculate $f_{\text {RNPP }}$ i.e. proportion of root production in relation to TNPP. The RNPP fluctuated from 20 to $359 \mathrm{~g} \mathrm{DM} \mathrm{m}^{-2} \mathrm{yr}^{-1}$ on compared sites. Differences in RNPP values were also reflected in assessed $f_{\mathrm{RNPP}}$. Values varied from different geographical sampling locations (Table 2). Across all sites, $f_{\text {RNPP }}$ ranged between 0.06 and 0.51 (Table 2). Grasslands growing in dry habitats (41-100 and 0.06-0.21 $\mathrm{g} \mathrm{DM} \mathrm{m}^{-2}$, respectively) and in the highest mountain sites (20-162 and $0.05-0.27 \mathrm{~g} \mathrm{DM} \mathrm{m}^{-2}$, respectively) tended to have the lowest yearly root increments and $f_{\text {RNPP }}$ as well. In contrast, highland and mountain sites at a lower altitude (Kameničky, Suchý vrch and Černá Ostravice valley sites) had higher yearly root increments and $f_{\mathrm{RNPP}}$ coefficients (157-359 and 0.24-0.51 $\mathrm{g} \mathrm{DM} \mathrm{m}^{-2}$, respectively).

\section{Relationships of $f_{R N P P}$ and climatic factors}

Results from different regions of sampling locations indicated that the $f_{\mathrm{RNPP}}$ values did not simply increased or decreased with altitude, MAT and MAP. The relationship of $f_{\text {RNPP }}$ with these factors was nonlinear. Nevertheless, quadratic regressions showed that these factors significantly affected $f_{\mathrm{RNPP}}$ coefficients (Figs $1-3$ ). The $f_{\mathrm{RNPP}}$ partly tended to increase with increasing climatic factors, but subsequently this coefficient (proportion of root production) decreased in sites with the highest altitude, MAT or MAP (Figs 1-3).

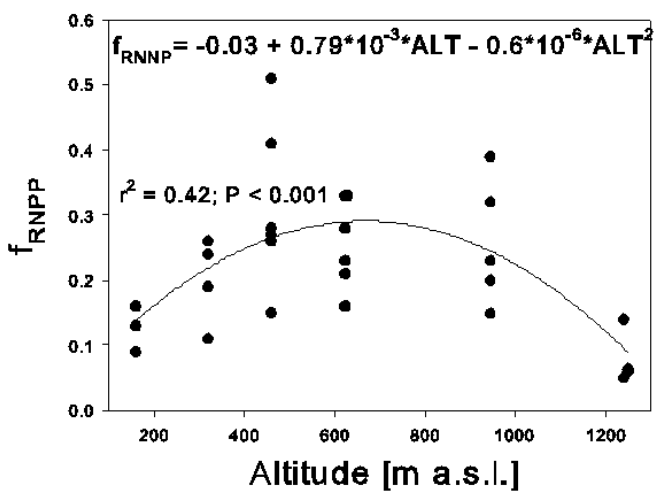

Fig. 1. Relationship of the fraction of root net primary productivity to total NPP $\left(\mathrm{f}_{\mathrm{RNPP}}\right)$ and altitude (ALT). 


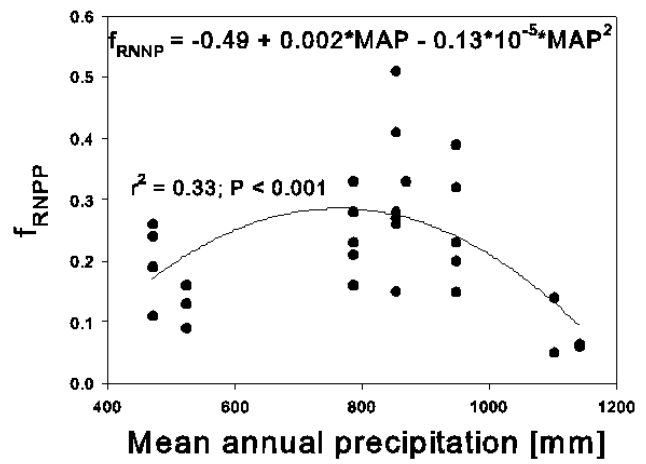

Fig. 2. Relationship of the fraction of root net primary productivity to total NPP $\left(\mathrm{f}_{\mathrm{RNPP}}\right)$ and mean annual precipitation (MAP).

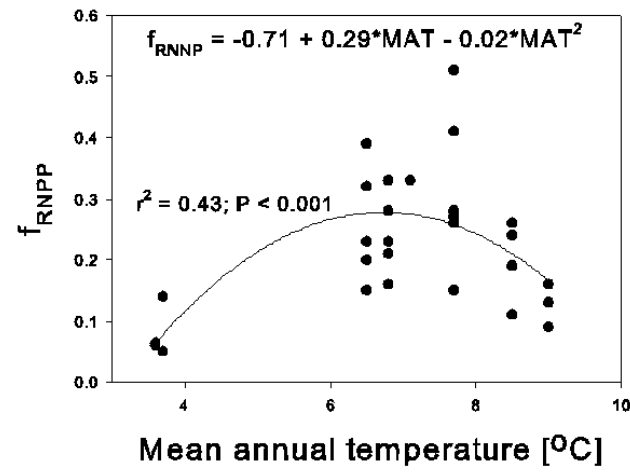

Fig. 3. Relationship of the fraction of root net primary productivity to total NPP $\left(\mathrm{f}_{\mathrm{RNPP}}\right)$ and mean annual temperature (MAT).

\section{Discussion}

\section{Variations in below-ground plant parts on different sites}

The pattern of biomass partitioning may be the results of plant species adaptation and responses to both internal and environmental stimuli (Hui, Jackson, 2006). Their results indicate that plants maintain a certain response to growth and biomass partitioning with annual environment of each habitat. The results of this study also indicate that recorded values of the TBDM, RNPP and $f_{\text {RNPP }}$ varied in geographical locations of sampling and type of grassland. In this study, TBDM across analyzed sites ranged between 831 and $2592 \mathrm{~g} \mathrm{DM} \mathrm{m}^{-2} \mathrm{yr}^{-1}$, which is consistent with results summarised by Hui and Jackson (2006). They reported that mean TBDM varied from 228 to $2147 \mathrm{~g} \mathrm{DM} \mathrm{m}^{-2} \mathrm{yr}^{-1}$. In addition, the highest values of TBDM in this study were lower than values estimated previously in moist meadows (Fiala, 1993, 2010).

Also RNPP values presented in this paper (20-359 $\left.\mathrm{g} \mathrm{DM} \mathrm{m}^{-2} \mathrm{yr}^{-1}\right)$ confirm with other available published data on the root production in meadow stands of various regions assessed by in-growth technique and compiled by Fiala $(1997,2010)$. These data ranged mostly between 173 and $567 \mathrm{~g} \mathrm{~m}^{-2} \mathrm{yr}^{-1}$. Our data, gathered previously in alluvia of the warmer and drier region of southern Moravia, supported results of this study, because below-ground biomass production average only $40 \%$ of the below-ground biomass production in meadow stands of Bohemian-Moravian Highland (e.g. Pilát, 1969; Jakrlová, 1971). Thus, the present data confirmed our first assumption because lower allocation of root biomass was recorded in drier conditions at warmer sites on the contrary to larger root formation in wet and cool highland sites. However, data assessed with the help of in-growth core technique collected roots, but did not contain rhizomes and below-ground grass shoot basses. Thus, for example, productions of Calamagrostis rhizomes and shoot bases were not included in our calculation. Therefore data concerning Calamagrostis (four site-year samples) are partly underestimated. Effect of above-mentioned environmental factors on root and rhizome production can also 
be intensified by negative impact of pollution (soil acidification, nitrogen excess, etc.) occurring in deforested areas of the uppermost mountain zone (e.g. Pyšek, 1993; Koppisch, 1994; Fiala, 2000).

\section{Relationships of $f_{R N P P}$ and climatic factors}

By summarizing 40 field biomass estimations, we try to evaluate regional and altitudinal variability in $f_{\mathrm{RNPP}}$ and the relationships of $f_{\mathrm{RNPP}}$ with climatic variables. In contrast to data found by Hui and Jackson (2006) we did not find that $f_{\text {RNPP }}$ was negatively correlated with MAT and MAP across sites. Altitude can determine values of these climate factors. However, Fitter et al. (1998) deduced from their field experiment that neither root production nor root death rate was a simple function of altitude. They noticed that increased root accumulation in summer was a function of changes in the length of the growing season, not of soil temperature.

Our data indicate, in accordance with our assumptions, that lower amount of precipitation and higher temperature can be associated with low root increments in South Moravia sites. On the other hand, the low temperature and the influence of wet acid deposition can be reflected in lower root production in the Beskydy Mts (Kněhyně and Smrk hills). Thus we found quadratic relationships between $f_{\mathrm{RNPP}}$ and studied climatic variables. Other different geographical and temporal responses of plants to climatic variables have been described in literature. For example, results showed that above-ground biomass production was more controlled by rainfall than by other factors. However, both the positive and negative relationships of BNPP (or RNPP) to climatic variables have been found (see Introduction). Experimentally obtained data (Fiala et al., 2009, 2012) showed that there was positive effect of precipitation on root growth in various grasslands during 5 years. Similarly, water availability was the most limiting factor for $f_{\text {RNPP }}$ in tall prairie (Xu et al., 2012).

$\mathrm{Ni}$ (2004) summarised that productivity correlation implied that above-ground productivity is more controlled by rainfall, whereas below-ground and total productivity is more influenced by temperature in the temperate grasslands of northern China. The greater influence of temperature on below-ground productivity might be due to the high temperature in the growing season and the influence of soil temperature on the root system $(\mathrm{Ni}$, 2004). The high correlation between MAT and below-ground biomass was also confirmed in the temperate and tropical grassland worldwide (Gill et al., 2002). They found that belowground biomass was inversely related to MAT, while there was a poor relationship between below-ground biomass and MAP. According to Hui and Jackson (2006) the geographical relationships could be the result of long-term plant adaptation to local climates, and reflect the contribution of vegetation to variation in $f_{\mathrm{RNP}}$. Temporal relationships of $f_{\mathrm{RNPP}}$ and climatic variables within sites can be more complicated and could be site-specific.

As temperature continues to increase and precipitation decrease, plants may allocate relatively less below-ground, decreasing $f_{\mathrm{RNPP}}$. Such decrease can probably influence the storage of C below-ground, as well as C turnover (Hui, Jackson, 2006). They summarised a larger data set and stated that advantages and limitations of data synthesis occur. One is the availability of measurements and second variation of data quality across sites; therefore estimates of BNPP remain the limiting step in most. 


\section{Cluster of regions based on $f_{R N P P}$}

We found distinct patterns of variability in $f_{\text {RNPP }}$ across regions, and divergent responses of $f_{\text {RNPP }}$ to climatic variables. Our results showed that 13 sites could be clustered into three groups based on their variability in $f_{\mathrm{RNPP}}$ (Figs 1-3). Dry acid grasslands and meadows with eliminated floods in lowland had the smallest values of $f_{\mathrm{RNPP}}$. Similarly lower $f_{\mathrm{RNPP}}$ values were found on the opposite site of altitudinal gradient, i.e. in cooler conditions of the upper sites of mountains. The third larger group, submontane and mountain meadows, situated approximately in the central part of altitudinal gradient, had large values of $f_{\mathrm{RNP}}$. Our data partly corresponded with results summarised by Ni (2004) because he recorded the high BNPP in meadow and alpine grasslands and the low BNPP in desert and steppes. Typical plant species growing in a region tend to adjust to local environment through their biomasspartitioning strategies (Hui, Jackson, 2006). For example, plants growing in wet submontane meadows usually have proportionally more roots and larger $f_{\mathrm{RNPP}}$ (Fiala, 1997, 2010). Thus our last presumption was confirmed since studied grassland sites can be clustered into three main groups.

\section{Conclusion}

Relationships of $f_{\text {RNPP }}$ and climatic variables were rather more complicated than was presented by other authors (Ni, 2004; Hui, Jackson, 2006) and this knowledge represent new and important findings of this study. We did not find a simple negative linear relationship between $f_{\text {RNPP }}$ and MAT or MAP across sites, how it was described by above mentioned authors. Our results rather indicate quadratic regressions, because a smaller root production was recorded in relation to above-ground biomass production in both dry and warm conditions of lowland and very cool mountain sites affected by air pollution. Our results provide useful information in several respects. They provide cover of $f_{\text {RNPP }}$ across geographical and altitudinal scale. The geographical regression curve and climatic variables could also be used in modelling to improve model of $\mathrm{C}$ outputs in grasslands. Results can help in regional modelling studies and to the possible site-specific temporal responses to climatic variables.

\section{Acknowledgements}

This research was supported by national grants (GACR: 526/06/0556, MZeCR: QJ1220007) and with institutional support RVO: 67985939. This article is a product of the CzechGlobe Centre that is being developed within the OP RDI and co-financed from EU funds and the State Budget of the Czech Republic (CZ.1.05/1.1.00/02.0073).

\section{References}

Andrzejewska, L. (1991). Root production of some grass communities on peat soil in river valleys of Biebrza and Narew. Polish Ecological Studies, 17, 63-72.

Bakker, M.R., Augusto, L. \& Achat D.L. (2006). Fine root distribution of trees and understory in mature stands of marine pine (Pinus pinaster) on dry and humid sites. Plant Soil, 286, 37-51. DOI: 10.1007/s11104-006-9024-4.

Fay, P.A., Kaufman, D.M., Nippert, J.B., Carlisle, J.D. \& Harper C.W. (2008). Changes in grassland ecosystem function due to extreme rainfall events: implications for responses to climate change. Global Change Biology, 14, 1600-1608. DOI: 10.1111/j.1365-2486.2008.01605.x. 
Fiala, K. (1993). Underground biomass in meadow stands. In M. Rychnovská (Ed.), Functioning of meadow ecosystems (pp. 133-153). Praha: Academia.

Fiala, K. (1997). Underground plant biomass of grassland communities in relation to mowing intensity. Acta Scientarium Naturalium Academiae Scientarium Bohemicae Brno, 31, 1-54.

Fiala, K. (1998). Variation in belowground biomass of grass stands in deforested areas affected by air pollution in the Beskydy Mts. Ekológia (Bratislava), 17(Suppl. 1), 256-278.

Fiala, K. (2000). Root and rhizome growth of grasses Calamagrostis arundinacea and C. villosa on deforested sites in response to pollution and climatic impacts. Biologia, 55, 91-98.

Fiala, K. (2001). The role of root system of Calamagrostis epigejos in its successful expansion in alluvial meadows. Ekológia (Bratislava), 20, 292-300.

Fiala, K., Záhora, J., Tůma, I. \& Holub P. (2004). Importance of plant matter accumulation, nitrogen uptake and utilization in expansion of tall grasses (Calamagrostis epigejos and Arrhenatherum elatius) into acidophilous dry grassland. Ekológia (Bratislava), 23, 225-240.

Fiala, K., Tůma, I. \& Holub P. (2009). Effect of manipulated rainfall on root production and plant belowground dry mass of different grassland ecosystems. Ecosystems, 12, 906-914. DOI: 10.1007/s10021-009-9264-2.

Fiala, K. (2010). Belowground plant biomass of grassland ecosystems and its variation according to ecological factors. Ekológia (Bratislava), 29, 182-206. DOI: 10.4149/ekol_2010_02_182.

Fiala, K., Tůma, I. \& Holub P. (2012). Interannual variation in root production in grasslands affected by artificially modified amount of rainfall. The Scientific World Journal, Article ID 805298, 10 pages. DOI: 10.1100/2012/805298.

Fitter, A.H., Graves, J.D., Self, G.K. \& Brown T.K. (1998). Root production, turnover and respiration under two grassland types along an altitudinal gradient: influence of temperature and solar radiation. Oecologia, 114, 2030. DOI: $10.1007 / \mathrm{s} 004420050415$.

Gill, R.A. \& Jackson R.B. (2000). Global patterns of root turnover for terrestrial ecosystems. New Phytol., 147, 13-31. DOI: 10.1046/j.1469-8137.2000.00681.x.

Gill, R.A., Kelly, R.H., Parton, W.J., Day, K.A., Jackson, R.B., Morgan, J.A., Scurlock, J.M.O., Tieszen, L.L., Castle, J.V., Okima, D.S. \& Zhang X.S. (2002): Using simple environmental variables to estimate belowground productivity in grasslands. Glob. Ecol. Biogeogr., 11, 79-86. DOI: 10.1046/j.1466-822X.2001.00267.x.

Hayes, D.C. \& Seastedt T.R. (1987). Root dynamics of tallgrass prairie in wet and dry years. Can. J. Bot., 65, 787-791. DOI: $10.1139 / \mathrm{b} 87-105$.

Holub, P. (2002). The expansion of Calamagrostis epigejos into alluvial meadows: comparison of aboveground biomass in relation to water regimes. Ekológia (Bratislava), 21, 27-37.

Holub, P., Fabšičová, M., Tůma, I., Záhora, J. \& Fiala K. (2013a). Effects of artificially varying amounts of rainfall on two semi-natural grassland types. J. Veg. Sci., 24(3), 518-529. DOI: 10.1111/j.1654-1103.2012.01487.x.

Holub, P., Tůma, I. \& Fiala K. (2013b). Effect of fertilization on root growth of submontane Polygono-Cirsietum meadow. Plant, Soil and Environment, 59, 342-347.

Hrabě, F., Straka, J. \& Rosická L. (2002). Produkční a strukturální změny polopřirozeného a nově setého lučního společenstva v oblasti CHKO Ždárské vrchy. In V. Krajčovič. (Ed.), Ekológia trávného porastu VI. (pp. 220-227). Banská Bystrica: Výskumný ústav trávných porastov a horského polnohospodárstva.

Hui, D. \& Jackson R.B. (2006). Geographical and interannual variability in biomass partitioning in grassland ecosystems: a synthesis of field data. New Phytol., 169, 85-93. DOI: 10.1111/j.1469-8137.2005.01569.x.

Ibrahim, L., Proe, M.F. \& Cameron A.D. (1997). Main effects of nitrogen supply and drought stress upon wholeplant carbon allocation in poplar. Can. J. For. Res., 27, 1413-1419. DOI: 10.1139/x97-080.

Jakrlová, J. (1971). Flooded meadow communities. An analysis of productivity in a dry year. Folia Geobot., 6, 1-27.

Jakrlová, J. (1996). Variability of aboveground production of Calamagrostis villosa in localities exposed to emissions in the region of the Beskydy Mts. In K. Fiala (Ed.), Grass ecosystems of deforested areas in the Beskydy Mts (pp. 75-82). Brno: ASCR, Institute of Landscape Ecology.

Köchy, M. \& Wilson S.D. (2004). Semiarid grassland responses to short-term variation in water availability. Plant Ecol., 174, 197-203. DOI: 10.1023/B:VEGE.0000049098.74147.57.

Koppisch, D. (1994). Nährstoffhaushalt un Populationsdynamik von Calamagrostis villosa (Chais.) J.F. Gmel, einer Rhizompflanze des Unterwuchses von Fichtenwäldern. Bayreuther Forum Ökologie, 12, 1-187.

Melillo, J.M., McGuire, A.D., Kicklighter, A.W., Moore, B.I., Vorosmary, C.J. \& Schloss A.L. (1993). Global climatechange and terrestrial net primary production. Nature, 363, 234-240. DOI: 10.1038/363234a0.

Milchunas, D.G. (2012). Biases and errors associated with different root production methods and their effects on field estimates of belowground net primary production. In S. Mancuso (Ed.), Measuring roots: An updated ap- 
proach (pp. 303-339). Berlin: Springer. DOI: 10.1007/978-3-642-22067-8_16.

$\mathrm{Ni}$, J. (2004). Estimating net primary productivity of grasslands from field biomass measurements in temperate northern China. Plant Ecol., 174, 217-234. DOI: 10.1023/B:VEGE.0000049097.85960.10.

Pilát, A. (1969). Underground dry weight in the grassland communities of Arrhenatheretum elatioris alopecuretosum pratensis R. Tx. 1937 and Mesobrometum erecti stipetosum Vicherek 1960. Folia Geobot., 4, 225-234.

Pyšek, P. (1993). What do we know about Calamagrostis villosa? A review of the species behaviour in secondary habitats. Preslia, 63, 9-20.

Qaderi, M.M., Kurepin, L.V. \& Reid D.M. (2006). Growth and physiological responses of canola (Brasica napus) to three components of global climate changes: Temperature, carbon dioxide and drought. Physiologia Plantarum, 128, 710-721. DOI: 10.1111/j.1399-3054.2006.00804.x.

Risch, A.C., Jurgensen, M.F. \& Frank D.A. (2007). Effects of grazing and soil micro-climate on decomposition rates in a spatio-temporally heterogeneous grassland. Plant Soil, 298, 191-201. DOI: 10.1007/s11104-007-9354-x.

Rychnovská, M. (1983). Grasslands: A multifunctional link between natural and man-made ecosystems. Ekológia (ČSSR), 2, 337-345.

Stanton, N.L. (1988). The underground in grasslands. Annu. Rev. Ecol. Syst., 19, 573-589. DOI: 10.1146/annurev. es.19.110188.003041.

Titlyanova, A.A., Romanova, I.P., Kosykh, N.P. \& Mironycheva-Tokareva N.P. (1999). Pattern and process in aboveground and below-ground components of grassland ecosystems. J. Veg. Sci., 10, 307-320. DOI: 10.2307/3237060.

Tomaškin, J. \& Tomaškinová J. (2012). The ecological and environmental functions of grass ecosystems and their importance in the elimination of degradation processes in agricultural landscape. Carpathian Journal of Earth Environmental Sciences, 7, 71-78.

Xu, X., Niu, Sh., Sherry, R.A., Zhou, X. \& Zhou J. (2012). Interannual variability in responses of belowground net primary productivity (NPP) and NPP partitioning to long-term warming and clipping in a tallgrass prairie. Global Change Biology, 18, 1648-1656. DOI: 10.1111/j.1365-2486.2012.02651.x.

Yahdjian, L. \& Sala O.E. (2006). Vegetation structure constrains primary production response to water availability in the Patagonian steppe. Ecology, 87, 952-962. DOI: 10.1890/0012-9658(2006)87[952:VSCPPR]2.0.CO. 